\title{
Spatial Tax Competition and Domestic Wages
}

\author{
Kevin A. Hassett, AEI \\ Aparna Mathur, AEI
}

Current Version: November 2010

\begin{abstract}
Using a unique, self-compiled dataset on international tax rates, we explore the link between taxes and manufacturing wages for a panel of 65 countries over 25 years. We find, controlling for other macroeconomic variables, that wages are significantly responsive to corporate taxation. Higher corporate tax rates depress wages. We also find that tax characteristics of neighboring countries, whether geographic or economic, have a significant effect on domestic wages. These results are consistent with the frequently employed assumptions in the public finance literature that capital is highly mobile, but labor is not. Under these conditions labor will bear the burden of capital taxes.
\end{abstract}

JEL Codes: F21, H2, J3, C3 


\section{Introduction}

The incidence of the corporation income tax is a fundamental question in the study of public economics. Corporation income taxes are levied on the earnings of capital in the corporate sector of the economy. Corporations, or businesses, however are legal structures that bring together shareholders or investors, workers and consumers. Therefore it is natural to question which of these entities, in fact, bears the economic burden of repaying the tax. ${ }^{i}$ The contribution of economic theory to this study has been the recognition that while the statutory burden of the tax is on corporate income, the economic burden could be shifted forward to consumers in the form of higher prices, to shareholders in the form of lower returns or shifted backward to workers in the form of lower wages. ${ }^{\text {ii }}$

In this paper, we abstract from the effect of the corporate income tax on shareholder returns and consumer prices and focus on the extent to which workers may inadvertently bear a portion of the corporation tax. This narrow focus is justified somewhat since economic models relying on open economy assumptions predict no changes in output prices and rates of return to capital due to tradability of output and perfect capital mobility. In these models, workers are shown to bear a large part of the corporate tax burden since the only option for firms to remain competitive is to pass on the tax to workers in the form of lower wages. For instance, Harberger (1995) shows that under these conditions, workers could bear more than $100 \%$ of the corporate tax burden.

The idea that workers may bear a portion of the corporate income tax is neither surprising nor new. Basic incidence analysis suggests that the burden of the tax will 
always be larger on the side of the market that is more inelastic. In the short run, the incidence will necessarily be borne out of the earnings of fixed capital since the supply of capital is fixed. However, it is the long run effects which are of greatest theoretical and practical interest. Since capital is relatively more mobile in the long-run than labor (which is relatively inelastically supplied), labor could bear a larger portion of the tax burden.

The actual mechanism by which the tax burden is transferred to workers is a question of extreme interest in our paper. One channel through which this works is the effect of a higher tax rate on capital investment. Since the imposition of the corporate tax lowers the post-tax return on capital, this reduces the firms' incentive to invest. In the long-run, as the stock of capital declines, worker productivity suffers since workers have relatively lower stocks of capital to work with. A decline in the marginal product of labor then lowers the wage.

These effects could be large in a domestic setting, but are probably magnified in an open economy setting. With open borders and free capital mobility, corporate capital can move to other countries that have lower rates of corporate taxation. Over the previous decade, almost every member of the European Union has cut its rate. Germany has reduced its corporate rate from around 40 percent to 30 percent. U.K. has also cut its corporate rate from 30 percent to 28 percent. These reductions reflect a growing perception among governments worldwide that low corporate taxes attract businesses and investment and stimulate long-term competitiveness. The spur in economic activity as a result of the shifting of investment to low-tax jurisdictions is likely to have long-term 
wage impacts. Our paper attempts to model this tax competition among spatial neighbors by including as an explanatory variable, the average tax rate in the neighboring country.

Accordingly, the paper addresses two main questions: One, do corporate tax rates systematically affect wage rates? Two, if tax rate differentials lead to international capital mobility, are wages in the domestic economy affected by taxes in competing economies? These questions are addressed using a sample of developing and developed economies. Our empirical results indicate that domestic corporate taxes are negatively and significantly related to wage rates across countries. Further, relatively higher corporate taxes in a country's neighbors lead to higher domestic wages due to capital flight from high tax jurisdictions.

Section II provides a literature survey. Section III discusses the data and presents summary statistics. Section IV discusses regression results. Section V concludes.

\section{Literature Review}

The debate surrounding the incidence of the corporate income tax has a long history and evolution, starting from Harberger's seminal 1962 contribution which placed the entire burden of the corporate tax on capital, to his most recent 2006 paper in which he concludes that for a small country which is a price taker in product markets for tradable goods "labor will bear more than the full burden of the corporation income tax".

Feldstein (1974) develops a theoretical model of the incidence of a corporate income tax. Replacing the Harberger (1962) assumptions of a fixed capital stock in a static model with a growing economy with a variable savings rate, Feldstein (1974) concludes that a substantial fraction of the burden of a corporate tax may fall on workers. 
Other studies along the same vein which argue that the burden of the tax would fall on the immobile factors include Bradford (1978), Kotlikoff and Summers (1987), Mutti and Grubert (1985) and Randolph (2006). The paper by Randolph suggests that domestic labor and capital bear the tax burden roughly in proportion to their factor income shares: labor bears $73 \%$ of the tax burden. A few authors however question the assumptions of perfect capital mobility and product substitutability which drive Harberger's open economy results. For instance, Gravelle and Smetters $(2001,2006)$ and Gravelle (1994) argue that relaxing these assumptions leads us back to the closed economy outcome of capital bearing the larger share of the tax burden.

While much of the debate on the incidence of the corporate income tax has been waged on theoretical grounds, in recent times there has been a spurt of empirical papers that have attempted to address the topic using real world data on corporate tax rates and wage rates. For instance, Arulampalam et al. (2007) use company level data for nine major European countries for the period 1996-2003. Their results suggest that $\$ 1$ of additional tax reduces wages by 49 cents in the long run. This is the direct effect which arises as a result of wage bargaining between the firm and workers. The paper does not attempt to estimate the indirect effect which works through a lower capital stock, therefore it is hard to predict what the total impact would be and how it compares to our estimates. Mihir A. Desai, C. Fritz Foley, and James R. Hines (2007) use aggregate data on the activities of US companies in around 50 countries in four years to estimate jointly the impact of the corporate income tax on the wage rate and the rate of profit. Fixing the sum of these effects to be unity, they find that between 45 and 75 percent of the corporate tax borne is borne by labor with the remainder falling on capital. Again, fixing the sum of 
the effects to be unity abstracts from the indirect effects of the deadweight cost, which if included would generate a total effect in excess of unity. Felix (2007) also finds a large negative effect of corporate taxes on worker wages. Using cross-country panel data from the Luxembourg Income Study for 19 countries, she estimates that a 10 percentage point increase in the corporate tax rate would reduces annual gross wages by 7 percent. Using U.S. data on corporate tax revenues and total wages, these estimates predict that labor's share of the tax burden is more than four times the magnitude of the corporate tax revenue collected in the U.S.. The paper does not distinguish between long-run and shortrun effects. Hence none of the papers so far has estimated the long-run impact or what Arulampalam et al. (2007) refer to as the indirect impact of corporate taxation on wages. Further, none of the papers accounts for the spatial tax competition that is essential to any such study.

In addition, it appears that capital flows to a particular country are also significantly influenced by corporate tax rates in competing countries. After large reductions in statutory corporate tax rates by Ireland, UK and USA in the mid 1980's, other OECD countries also cut their rates perhaps out of a concern that they would lose investments. ${ }^{\text {iii }}$ The international tax literature, recently summarized by Gordon and Hines (2002) and Devereux and Griffiths (1998) finds that mobile capital may often flow to low tax jurisdictions. If there is a drop in investment in relatively high-tax countries, this would reduce the amount of capital available to workers and thus reduce real wages in that country. Hence if tax competition is prevalent, then investment may not only be influenced by the level of rates but also by relative rates. Accordingly, it is important to explore not only the impact of levels of tax variables, but also the impact of relative tax 
variables for competing countries. Hence our analysis extends existing studies on wage determination by allowing for tax "competition" to influence wages, i.e., we allow taxes in competitive neighbor countries to influence domestic wage levels. ${ }^{\text {iv }}$

\section{Wage Determination Models}

To date, studies seeking to explain the cross-country variation in wage growth have not focused on the role of capital taxation. Rodrik (1999) finds that there is a robust and statistically significant association between the extent of democracy and the level of manufacturing wages in a country. This holds even after controlling for labor productivity and per capita incomes. Freeman and Ostendorp (2000) explain crosscountry differences in terms of the level of gross domestic product per capita and unionization and wage setting institutions. Rama (2003) concludes that in the short run, wages fall with openness to trade and rise with foreign direct investment, but after a few years the effect of trade on wages is reversed. At a micro level, the widening wage distribution in the United States has been explained in terms of de-unionization and the erosion of the real value of the minimum wage (DiNardo, Fortin and Lemieux, 1996). Card, Kramarz and Lemieux (1996) similarly emphasize labor market rigidities as important factors. Katz (1999) points to the increasing use of computers and computer based technologies as affecting the relative demand for skilled workers, and wage inequality. Other papers, such as Davis and Henrekson (2004) study the effect of high personal income tax rates on hours worked in the market sector and other labor market outcomes. Some papers also study the effect of foreign direct investment on wage determination in a spatial setting. Feenstra and Hanson (1995) find that increased foreign 
direct investment in Mexico, just across the US border, caused an increase in the relative wages of skilled workers, in both countries along the border. They, however, did not explicitly model or estimate this relationship using regression analysis or spatial econometrics techniques.

\section{Data Sources and Descriptions}

The data cover the period 1981-2005 and include 65 countries. $^{\mathrm{v}}$ The dependent variable in the empirical analysis is the average nominal U.S. dollar wage earned in manufacturing per hour. The main source of data on wages is the Labor Statistics database available from the International Labor Organization (http://laborsta.ilo.org/). This source provides information on wages for a broad sample of countries, for the period 1981-2005. (For a detailed explanation of the wage data, see Appendix A.2). International comparability of the data is made possible through use of various controls for differences in coverage and definitions. In most countries, the statistics on wages refer to "wages and salaries" which include direct wages and salaries, bonuses and gratuities, etc. whereas in some countries they refer to "earnings", which include, more broadly, all compensation such as paid leave, pension and insurance schemes. We then converted these total wage payments to hourly wage payments by dividing by the total number of hours worked, data which was again obtained from the ILO. ${ }^{\mathrm{vi}}$ We check for the robustness of empirical results when controls for differences in coverage are included. Average wages have been rising over the period 1981-2005 for all countries, though there is wide variation in countries both cross-sectionally and over time. ${ }^{\text {vii }}$ 
The other key variables in this paper are the tax rate variables. For these we draw on a new source, the AEI International Tax Database. The AEI tax database has been compiled over a number of years and includes information on several tax variables, such as (national and local) corporate taxes, personal income taxes, VAT, employer and employee payroll taxes, etc for about 128 countries starting in 1981. The main source for the corporate and personal income tax data has been the PriceWaterhouseCoopers "Corporate Taxes Worldwide Summaries" and "Individual Taxes Worldwide Summaries", however several other sources (detailed in Appendix A.1) have been used to validate the numbers. An attempt has been made as far as possible to standardize the definition of the tax rate used across countries, and to incorporate all the information

available in the corporate tax summaries. ${ }^{\text {viii }}$ For details on comparability issues, see Appendix A.1.

We control for differences in personal income taxation as well. To do this, we use average and median personal income tax rates from the AEI International Tax Database. The tax database has information on the number of tax brackets and the corresponding tax rate for each country. We constructed average and median tax rates using these.

\section{Empirical Model}

Using the Harberger model as our motivation, but allowing for long-run changes and international capital mobility to affect wages, our baseline empirical specification is as follows:

$$
\begin{aligned}
& \sum_{t_{s}} w_{i t}=\alpha_{i}+\beta_{1} \tau_{i t}+\beta_{2} v_{i t}+\beta_{3} \sum_{j=1}^{n} w_{i j t} \tau_{j t}+\bar{P}_{i t}+D_{t_{s}}+\varepsilon_{t_{i}} ; \mathrm{s}=1, . ., 5 \\
& \text { where } t_{1}=1981-1985, \mathrm{t}_{2}=1986-1990,1991-1995,1996-2000,2001-2005
\end{aligned}
$$


The dependent variable in this specification is $w_{i t}$, the five year $(\log )$ average of the nominal US\$ wage rate in manufacturing for country $i$ at time $t$. We use five year averages over five distinct sub-periods. Country-specific fixed effects are captured by . To ensure exogeneity of the right hand side variables, we use beginning-of-period values of , the (Log) Top Statutory Corporate Tax Rate, $(\log )$ Value Added per worker $\left(v_{i t}\right)$ in manufacturing. ${ }^{\text {ix }}$ Following Rodrik (1999), we also included an index of average consumer prices which is comparable across countries. This captures cost-of-living differences across countries that are not captured by exchange rate conversions. We use the five year average of this index since it works like a deflator for our nominal wage variable. The index is available from the Penn World Tables. Finally, we also include dummy variables for each sub-period in our sample.

We use beginning of period (or lagged) values of the independent variables since in our model corporate taxes only indirectly affect wages, by first affecting the capitallabor $(\mathrm{K} / \mathrm{L})$ ratio. Thus the response of wages to corporate taxation depends first on the speed with which capital-labor ratios adjust to corporate taxation, and second, on the speed with which wages adjust to changes in productivity as a result of changes in K/L. Domestic firms may respond to lower corporate taxes by increasing their stock of capital and theory suggests that this adjustment may not be instantaneous. Global capital may be more flexible, but will only gradually flow into the low-tax country thereby increasing the stock of domestic capital. Wages will respond to this increase in capital-labor ratios with some lag as firms observe productivity gains and workers renegotiate fixed wage contracts. Hence we look for changes over long periods of time. 
We present results with different measures of the corporate tax rates, such as the top national corporate tax rate, the effective marginal (EMTR) and the effective average corporate tax rate (EATR). A word about these rates is warranted here since we are not using the realized values of taxes and incomes to generate these rates. In fact, these rates are constructed using the methodology discussed in Devereux and Griffith (1999). The EMTR is the tax rate on the marginal investment, where the marginal investment equates the net present value of the income stream to the net present value of costs from the investment. The EATR can be computed as the difference between the pre-tax and the post-tax economic rent scaled by the net present value of the pre-tax income stream. ${ }^{\mathrm{x}}$

We computed the EATR and the EMTR for all countries in the sample and for each time period using the methodology outlined in Devereux et al (1999), assuming fixed parameter values for the economic depreciation rates, the inflation rate and the annual discount rate. ${ }^{\mathrm{xi}}$

An interesting addition in the paper is the exploration of tax competition issues. Wages in the home country are affected by capital flows to the country as we discussed above. However, capital flows are subject to the forces of competition from other countries that are keen to divert these flows to themselves. Tax competition occurs through the lowering of relative tax rates across countries. Therefore, to account for the effect of tax rates in other countries on capital flows and therefore wages in the home country, we include variables measuring the weighted average tax rates in similar income and geographically close economies. This follows the standard spatial regression literature as summarized by Anselin (1999). To our knowledge, this is the first paper to explicitly include spatial variables in a wage regression. 
The spatial weights matrix takes the form, $W_{t}=\left[W_{1 t .}^{\prime}, \ldots \ldots \ldots ., W_{N t}^{\prime}\right]^{\prime}$. At any time $t$, the $i$ th row of this matrix is given by $W_{i t}$, which specifies "neighborhood sets" for each observation $i$. The $i j$-th element of $W_{t}$, namely, $w_{i j, t}$, is positive if $j$ is a "neighbor" of $i$, and is zero otherwise. In our model, we consider many forms of the weighting matrix. One is based on regional economic weights. In this, the countries are assigned to be "neighbors" if they are in the same region as country $i$. For example, Zambia would have as its neighbors, Zimbabwe, Malawi and Mauritius since they are all in the East African region, but would not include Bolivia, Australia, etc. since they are in other regions. Countries within the same region would then be weighted by their GDP. A second form of the weighting matrix is based on Income weights, i.e., countries within the same income group, such as high income, low income, or upper middle income, etc. are classified as neighbors. These countries are then weighted by their GDP. The third kind of weighting we used was to assign distance weights to countries within the same income group.

These weighting matrices were used to create weighted averages of corporate tax rates in "neighbor" countries. In somewhat more detail, the ijth element of the weighting matrix at time $t$, is,

$$
w_{i j t}=\frac{G D P_{i j t}}{\sum_{k} G D P_{i k t}} \quad \text { where } k \text { is the number of "neighbor" countries for country } i \text {. }
$$

The weighting matrix based on distance is defined in a similar manner. By convention, a cross sectional unit is not a neighbor to itself, so that the diagonal elements of $W_{t}$ are all zero i.e $w_{i i, t}=0$. The significance of these spatial variables in the regressions suggests that tax competition affects capital flows and wages in the home country. 
We expand upon the baseline regression by including variables to measure the openness of the economy. These include trade as a fraction of GDP (available from the ILO KILM database) and an index of capital mobility (from the Economic Freedom of the World Database). We also experiment with additional variables such as the level of schooling, computerization and urbanization, highlighted by other papers in the literature.

To allow for the effect of labor market institutions, we use two variables. One of these measures the percentage of workers in a country covered by collective bargaining agreements, as a percent of total salaried or dependent workers. The second is a broader measure which is a count of the cumulative number of ILO conventions ratified by the country. The ILO conventions include ratification of conventions on child labor, forced or compulsory labor, discrimination, the right to organize and the right to bargain collectively. Thus the greater the number of ratified conventions, the greater the protection of workers rights. Information on these variables is available from the Fraser Institute's Economic Freedom of the World dataset and the World Bank Labor Market Database (WBLMD), (Rama, 1996), respectively.

Following Rodrik (1999), ideally we would like to include both the level of gross domestic product (GDP) per capita (available from Penn World Tables) and manufacturing Value Added (MVA) per worker in the same regression. We obtained value added per worker data from the ILO. The correlation between this variable and the GDP variable is high, above 0.70 . Hence while we get similar results with the two variables, we report results using the Value Added variable to measure productivity. ${ }^{\text {xi }}$ Finally, we obtained information on capital-labor ratios from the extended Penn World 
Tables (Version 2.1, April 2006). ${ }^{\text {xii }}$ These data are not specific to the manufacturing sector and are not as extensive as for the tax variables in our model. ${ }^{\mathrm{xiv}, \mathrm{xv}}$

\section{Regression Results}

Table 1 provides summary tables for our data. The average dollar wage over our sample period for all countries was approximately $\$ 5.2$ per hour, while the average headline corporate tax rate was 34 percent. The effective average rate was lower at 30 percent, and the effective marginal rate was nearly 10 percentage points lower at 26.5 percent. In general average wages have increased between 1981 and 2005 from $\$ 3.5$ to $\$ 9$ per hour, while average tax rates have declined substantially. In 1981, the average top rate was 42 percent. In 2005, the average rate was 25 percent.

Table 2 presents the first set of regression results. All the regressions, unless otherwise stated, are estimated using fixed effects. All specifications also control for subperiod (time) dummies and the regressions are run allowing for clustering within country groups. This option calculates the Huber/White/sandwich estimator of variance and also allows observations within a group to be correlated. (We also ran GLS regressions allowing for panel heteroskedasticity with similar results).

The main variable of interest in this paper is the corporate tax rate. Regressions in Table 3 present estimates without the spatial variables. Column (1) presents a simple regression of the wage on the headline rate. The coefficient is highly significant at 5 percent, with a value of -0.69 . Therefore, the elasticity of wages w.r.t. corporate taxes is fairly high and negative. A 1 percent increase in the corporate tax rate is associated with a nearly 0.7 percent decrease in hourly wages. 
The coefficient on Log (Value Added) is also significant and positive, implying that higher worker productivity is associated with higher wages. Finally, the higher the price level of consumption, the higher the nominal wage.

In Columns (2) and (3), we test to see if the results from our baseline specification in Column (1) carry over to other measures of the corporate tax rate, such as the effective marginal tax rate and the effective average tax rate. The coefficient on the effective average tax rate variable is negative and significant at 5 percent, while on the effective marginal tax rate variable is significant only at 10 percent. These results are interesting since they suggest that the effective average rates of taxation matter almost as much for investment behavior as the statutory rate. Ultimately, firms care about what rate they will end up paying rather than the top rate, which a lot of firms can avoid paying through use of allowances and deductions. This supports the results of Devereux and Griffiths (1998) and Hassett and Hubbard (2002) of the impact of tax rates on investment for effective average tax rates.

In Column (4), we test our intuition that the longer term elasticity of wages w.r.t. the corporate tax is likely to be higher than the short-term elasticity. To do so, we do a regression of annual wages on the contemporaneous corporate tax rate and a one-year lagged wage rate. To account for endogeneity of the lagged wage rate and the corporate tax rate variables, we use GMM estimation. In this case, the elasticity of the wage w.r.t. the corporate tax variable is still above 1, though it is significantly lower in magnitude at approximately -0.3 , as opposed to -0.7 for our earlier regressions. Thus our results suggest that changes in corporate tax rates have long-term impacts on wages and productivity, and looking only at annual impacts may understate the true elasticity. 
As a final specification check, we divided countries into different regions and then re-estimated the equation using OLS with a set of region dummies, time dummies and the interaction of the two i.e region-specific time trends. This allows for common shocks across countries within a region and over time. For instance, many East European countries faced common economic and political shocks in the aftermath of the collapse of the Soviet Union which may have affected labor markets, productivity and wage levels. This was also true of the East Asian economies in the wake of the currency crisis in the late 1990s. Results in Column (5) suggest that adding these controls causes our estimated elasticity to be marginally higher than in earlier specifications.

In a recent paper, Gordon and Lee (2005) find that corporate taxation negatively affected country growth rates between 1970-1997. Our results suggest that these slower GDP per capita growth rates in the 1980s and 1990s may have also translated into slower wage growth, hence workers must be bearing some of the burden of corporate taxes. ${ }^{\text {xvi }}$

Table 3 presents results with the spatial tax variables included in the regression. These regressions incorporate measures of weighted average tax rates in "neighbor" countries. The choice of weights is guided by previous literature using spatial econometrics techniques, but we also experiment with different weighting schemes that are relevant to our analysis. ${ }^{\text {xvii }}$ In specification (1) "neighbor" countries are defined as all those countries that are in the same physical region, as described before. ${ }^{\text {xiii }}$ The weights that we use for these countries are GDP (per capita) weights. Thus every country is weighted by its economic strength in the region. In this specification, the domestic top corporate rate remains significant, but the weighted average tax rate in the region is not. 
This suggests that tax rate competition within regional neighbors is not a significant determinant of wage levels across countries.

In Column (2), we change the spatial neighbors by defining as neighbors those countries that are in the same income group (rather than in the same region). Countries within the same income group are then weighted by their respective GDP per capita. This specification would be justified if capital is more likely to flow between countries with the same per capita income rather than from very high to very low income countries or vice-versa. In this specification, the coefficient on the domestic corporate tax rate is marginally smaller than without the spatial tax variables. Also, the neighbor tax rates are significant and positive, suggesting that higher tax rates in neighbor countries have a positive impact on wages in the domestic country. The magnitude of the spatial tax coefficient is marginally higher than 1, suggesting that these tax linkages are stronger than for the regional neighbors.

Finally, column (3) presents results with another weighting scheme. While neighbors continue to be defined in terms of income groups, the countries within the group are now weighted using (inverse) distance weights. ${ }^{\text {xix }}$ Thus the farther the country, the lower the weight it receives within the group. In this specification the coefficient on the spatial tax variable is 0.6 , implying an elasticity of domestic capital formation to neighbor tax rates that is nearly the same as that with respect to domestic corporate tax rates. Thus tax linkages among countries within the same income group are a significant predictor of domestic wages. ${ }^{\mathrm{xx}}$

In Table 4, we tested for robustness of the coefficient on domestic and neighbor tax rates by including additional variables. These include the level of openness of the 
economy measured by the share of total trade in GDP and an index of capital mobility. We also included labor market regulations (as measured by the number of ILO conventions ratified by the country or the percent of workers covered by collective bargaining agreements). Finally, in unreported regressions, we included schooling (measured by enrollment at different levels of schooling, such as primary, secondary and tertiary (ILO)) and the extent of computerization (measured as the estimated number of personal computers in use as a fraction of the population, available from ILO). However,

none of these enters significantly, since we control for labor productivity directly. ${ }^{x x i}$ The estimated coefficient on corporate tax rates (the top rate, effective average and effective marginal rates) remains fairly similar across different specifications, and is significant at 10 percent. Further, the income weighted tax rates in income neighbor countries enter with coefficients higher than 1 , implying that all types of corporate taxation have an effect on wages, even after controlling for standard explanatory variables as suggested by the literature.

\section{Testing the Mechanism}

If we accept the results in Tables 2, 3 and 4 that corporate taxes affect wages, the natural next step is to question the mechanism by which they do so. Our hypothesis is that corporate tax rates affect wages through their impact on capital-labor ratios. We use different measures of the corporate tax rate, since high taxes on capital affect investment and therefore the capital stock by raising the user cost of capital. The user cost of capital is defined as the minimum return a firm needs to cover depreciation, taxes and the opportunity cost of funds (Jorgenson (1963), Hall and Jorgenson (1967), Auerbach (1983b)). Typically studies have found that high taxes lead to high user costs. ${ }^{\text {xxii }}$ 
Table 5 presents various tests of our hypothesis. In specification (1), we use a five year $(\log )$ average of the capital-labor ratio as the dependent variable. We find that all measures of corporate taxation, such as the top national corporate tax rate, the effective average and the effective marginal tax rate negatively affect capital formation, though only the first two measures show up as significant. The coefficient on (Log) Top Corporate Tax Rate implies a value of the elasticity of close to -0.14 . Clearly, higher top rates discourage capital formation. This result is even stronger for effective average tax rates which take into account depreciation allowances, inflation and interest rates and other factors that affect capital formation through the user cost of capital (specification 2). The estimated elasticity in this case is close to (negative) 0.16 . Other studies, using micro data and the actual user cost (not only the tax rate) estimate elasticities that are higher than this. Balistreri, McDaniel and Wong (2002) using industry data from the Bureau of Economic Analysis estimate elasticities in the range of 1-1.22, using different weighting schemes. Leung and Yuen (2005) using industry-level data on Canadian manufacturing estimate an elasticity of 0.33 . While our coefficient estimate is likely to be heavily biased due to aggregation, measurement issues and data constraints (the capitallabor ratio is not specific to the manufacturing sector), we present these results simply to show that different measures of corporate taxation can significantly and negatively affect capital-labor ratios. ${ }^{\text {xxiii }}$

The final column, Column (4), studies the link between high capital-labor ratios and average wages. Since capital-labor ratios are a direct proxy for worker productivity, it is not surprising that higher capital-labor ratios are associated with significantly higher 
wages. In general, a 1 percent increase in the capital-labor ratios is associated with a 0.45 percent increase in wages.

While these results are obviously not conclusive of the mechanism, much less that this is the only means by which corporate taxes affect workers, it is clearly evidence that corporate taxes could have long-term impacts on wages by affecting the availability of capital to combine with labor.

\section{Discussion of Results}

To check our results and in order to put bounds on the estimated coefficients, we did a back of the envelope calculation using results from the investment literature. ${ }^{\text {xiv }}$ Since our assumption is that corporate taxes affect investment in capital, we surveyed the recent literature on the elasticity of investment with respect to corporate tax rates. De Mooij and Ederveen (2003) conclude that the median value of the tax rate elasticity is around -3.3. Thus a 1 percent increase in corporate tax rates, on average, leads to a lowering of foreign direct investment by about 3 percent. They also report that the elasticities have increased over time, from 2.4 in 1987 to 3.7 by 2002 . The elasticity with respect to domestic investment is lower at around 1. If investment responds to corporate taxation, this will lead to changes in the capital stock over a period of time (and the capital-labor ratio for a given level of employment). Taking derivatives with respect to corporate taxes in the wage equation in the Solow model and using the widely accepted calibrated value of $\alpha$ (the share of capital) as 0.33 , these elasticities for foreign and domestic investment suggest that in the long-run, a lowering of corporate tax rates by 1 percent could cause wages to increase by $0.3-0.9$ percent. Hence our estimate of the elasticity is in the range predicted by the Solow wage equation. 


\section{Incidence Analysis}

It is interesting to analyze what our elasticity results imply for the incidence of the tax on labor incomes. To do a simple back-of-the-envelope calculation, we obtained data on corporate tax revenues and wages in the manufacturing sector. Note that our elasticity numbers relate the real wage per hour to the corporate tax rate. However, assuming a fixed stock of capital (which forms the tax base) and labor, this can be interpreted as the elasticity of the wage bill with respect to corporate tax revenues. The most recent data on revenues broken down by sector are available from the IRS for the year 2002. We therefore took the share of revenues generated by the manufacturing sector for that year and applied it to the most recent data available for tax revenues, which is 2006. For this year, the manufacturing sector revenues using the 2002 shares totaled $\$ 116$ billion. The total wage bill in manufacturing for the same year (data available from BEA) was $\$ 962$ billion. To calculate incidence, we multiplied the elasticity numbers obtained from the earlier regressions with the ratio of the wage bill to the tax revenues. Doing this using the elasticity w.r.t. the top corporate tax rate of 0.5 on average, we get that every dollar of additional tax revenue leads to a $\$ 4$ decrease in the real wage. However, the statutory headline rate may not be the most appropriate for doing this incidence analysis since the revenues depend on taxes actually paid, which depend upon depreciation allowances and other deductions. Therefore, we did the incidence analysis also w.r.t to the effective marginal (and average) tax rates. The elasticity of wages w.r.t. the effective marginal or average corporate tax rate varies from 0.4 to 0.6 , suggesting that a $\$ 1$ increase in the tax revenue leads to a nearly $\$ 3$ or $\$ 4$ decrease in the real wage. Note that these incidence 
calculations refer to the long run, i.e., they allow for a dynamic response of wages to corporate tax rate changes. Hence they would be higher than those obtained by other authors using annual data, since they account for long run changes in the capital stock affecting worker productivity. Using our annual income regressions, we find that a $\$ 1$ increase in tax revenues leads to a $\$ 2$ decrease in wages. Further, we are using the corporate tax revenues and wage data for the U.S. which may not be typical of our sample, which comprises low income countries as well. Therefore the incidence numbers would vary from country to country depending on the ratio of wages to corporate tax revenues.

\section{Conclusion}

To summarize, our results indicate that while personal income tax rates do not systematically affect wages, corporate taxes are significantly related to wage rates across countries. Our coefficient estimates suggest that a 1 percent increase in corporate tax rates leads to a $0.5-0.6$ percent decrease in wage rates. These results also hold for effective marginal and average tax rates. The coefficient estimate is (on average) close to 0.5. This suggests that wages are as likely to be influenced by the top statutory corporate tax rate, as by the effective marginal and average tax rates. Hence corporate tax cuts in the form of large allowances for depreciation of equipment and structures which reduce effective marginal rates could effectively influence wage levels as well.

We find evidence of international tax competition in the data. Capital formation and therefore wage rates are affected not only by domestic tax rates, but also tax rates in competing economies. The coefficient estimates for the spatial tax variables range from .6 to 1.4 suggesting significant quantitative impacts. Comparing different weighting 
schemes, the effects are largest when "neighbors" are defined as countries within the same income group, rather than within the same region. This suggests that tax competition is most intense among, say, high income countries such as Canada, France and Italy, rather than between geographic neighbors. This makes sense intuitively since there do not appear to be large transport costs associated with moving capital across large distances, so capital can easily flow to the most remunerative locations.

\section{References}

Alesina, Alberto, and Roberto Perotti, "The Welfare State and Competitiveness," American Economic Review, 87:5 (December 1997), 921-936.

Altshuler, Rosanne, and Timothy J. Goodspeed, "Follow the Leader? Evidence on European and U.S. Tax Competition," Department of Ecoomics Working Paper 200226, Rutgers University (2003).

Anderson, T.W., Introduction to Multivariate Statistical Analysis, New York: Wiley (1984).

Anselin, Luc, "Spatial Econometrics," (1999); available at: http://www.csiss.org/learning_resources/content/papers/baltchap.pdf

Arulampalam, Wiji, Michael Devereux, and Giorgia Maffini, "The Direct Incidence of Corporate Income Taxes on Wages," (2010); available at:

http://users.ox.ac.uk/ mast1732/RePEc/pdf/WP0707.pdf

Auerbach, Alan J., "Corporate Taxation in the United States." Brookings Papers on Economic Activity, 2 (1983a), 451-513.

Auerbach, Alan J., "Taxation, Corporate Financial Policy and the Cost of Capital," Journal of Economic Literature, 21:3 (1983b), 905-940.

Auerbach, Alan J., "Tax Reform and Adjustment Costs: The Impact on Investment and Market Value," International Economic Review, 30:4 (1989), 939-962. 
Auerbach, Alan J., "Who Bears the Corporate Tax?" NBER Working Paper W11686 (2005).

Auerbach, Alan J., and Kevin A. Hassett, "Tax Policy and Business Fixed Investment in the United States," Journal of Public Economics, 47 (1992), 141-170.

Auerbach, Alan J., and Kevin A. Hassett, "On the Marginal Source of Investment Funds," Journal of Public Economics, 87:1 (January 2003), 205-232.

Auerbach, Alan J., and Kevin A. Hassett, "Dividend Taxes and Firm Valuation: New Evidence," American Economic Review, Vol. 96:2 (2006), 119-123.

Balistreri, Edward, Christine McDaniel, and Eina Wong, "An Estimation of U.S. Industry -Level Capital-Labor Substitution Elasticities: Cobb-Douglas as a Reasonable Starting Point?" mimeo (2002). available at:

http://www.journalofpolicymodels.com/articles/prodfun_jpm.pdf

Barro, Robert J., "Religion and Economic Growth,” NBER Working Paper 9682 (2003).

Basinger, Scott J., and Mark Hallerberg, "Remodeling the Competition for Capital: How Domestic Politics Erases the Race to the Bottom," American Political Science Review, 98: 2 (2004), 261-276.

Besley, Timothy, and Harvey Rosen, "Sales Tax and Prices: An Empirical Analysis," Princeton University Economics Department, mimeo (1994).

Bingley, Paul, Gauthier Lanot, "The Incidence of Income Tax on Wages and Labor Supply," Journal of Public Economics, 83:2 (February 2002), 173-94.

Bloningen, Bruce A., Ronald B. Davies, Glen R. Waddell, and Helen T. Naughton, "FDI in Space: Spatial Autoregressive Relationships in Foreign Direct Investment," (2005); available at: http://darkwing.uoregon.edu/ bruceb/BDWN-2005-1003.pdf

Bradford, David F., "Factor Prices May be Constant, but Factor Returns are Not" Economics Letters, 1:3 (1978), 199-203.

Bradford, David F., "The Incidence and Allocation Effects of a Tax on Corporate Distributions," Journal of Public Economics, 15:1 (April 1981), 1-22.

Card, David, Francis Kramarz, and Thomas Lemieux, "Changes in the Relative Structure of Wages and Employment: A Comparison of the United States, Canada and France," NBER Working Paper 5487 (1996). 
CBO, "Corporate Income Tax Rates: International Comparisons," (November 2005); available at: http://www.cbo.gov/ftpdocs/69xx/doc6902/11-28-CorporateTax.pdf

Cummins, Jason G., Kevin A. Hassett, and R. Glenn Hubbard, "A Reconsideration of Investment Behavior using Tax Reforms as Natural Experiments," Brookings Papers on Economic Activity, 2 (1994): 1-74.

Davis, Steven J., and Magnus Henrekson, "Tax Effects on Work Activity, Industry Mix and Shadow Economy Size: Evidence from Rich-Country Comparisons", in R. Gómez-Salvador, A. Lamo, B. Petrongolo, M. Ward, and E. Wasmer (Eds.), Labour Supply and Incentives to Work in Europe (Cheltenham, UK: Edward Elgar, 2005), chapter 2, 4-104.

De Mooij, Ruud, and Sjef Ederveen, "Taxation and Foreign Direct Investment: a synthesis of empirical research," International Tax and Public Finance, 10 (2003), 673-693

Desai, Mihir, Fritz Foley, and James R. Hines, "Labor and Capital Shares of the Corporate Tax Burden: International Evidence," (2007); available at: http://www.people.hbs.edu/mdesai/publications.html

Devereux, Michael, Ben Lockwood, and Michela Redoano, "Capital Account Liberalization and Corporate Taxes," IMF Working Papers 03/180, International Monetary Fund (2003).

Devereux, Michael, and Rachel Griffith, "Taxes and the Location of Production: Evidence from a Panel of US Multinationals," Journal of Public Economics, 68 (June 1998), 335-367

Devereux, Michael, and Rachel Griffith, "The Taxation of Discrete Investment Choices," The Institute For Fiscal Studies, Working Paper Series No. W98/16 (1999).

Devereux, Michael, Rachel Griffith, and Alexander Klemm, "Corporate Income Tax Reforms and International Tax Competition," Economic Policy, 17: 35 (October 2002), 451-495.

DiNardo, John, Nicole M. Fortin, and Thomas Lemieux, "Labor Market Institutions and the Distribution of Wages, 1973-1992: A Semi-parametric Approach," Econometrica, 64:5 (July 1996), 1001-1044. 
Feldstein, Martin, and Marian Vaillant, "Can State Taxes Redistribute Income?" Journal of Public Economics, 68:3 (1998), 369-96.

Feldstein, Martin, "Incidence of a Capital Income Tax in a Growing Economy with a Variable Savings Rate," Review of Economic Studies, 40 (2974), 505-513.

Felix, R. Alison, "Passing the Burden: Corporate Tax Incidence in Open Economies," Federal Reserve Bank of Kansas City Working Paper (October 2007); available at: http://www.kansascityfed.org/Publicat/RegionalRWP/RRWP07-01.pdf

Franzese, Robert J. Jr., and Jude C. Hays, "Modelling Spatial Interdependence in Comparative and Internaitonal Political Economy with an Application to Capital Taxation,” (April 2005); available at: http://wwwpersonal.umich.edu/ franzese/FranzeseHays_MWPSA05.pdf

Freeman, Richard B., and Remco Oostendorp, "Wages Around the World: Pay Across Occupations and Countries," NBER Working Paper 8058 (2002).

Gordon, Roger H., "Taxation of Investment and Savings in a World Economy," American Economic Review, 76:5 (December 1986), 1086-1102.

Gordon, Roger H., and James Hines "International Taxation," NBER Working Paper 8854 (2002).

Gordon, Roger H., and Young Lee, “Tax Structure and Economic Growth," Journal of Public Economics, 89:5-6 (2005), 1027-1043.

Gordon, Roger H., and Wei Li, "Tax Structure in Developing Countries: Many Puzzles and a Possible Explanation,” NBER Working Paper 11267 (2005).

Gravelle, Jane G., and Kent Smetters, "Who Bears the Burden of the Corporate Tax in the Open Economy?" NBER Working Paper 8280 (May 2001).

Gravelle, Jane G., and Kent Smetters, "Does the Open Economy Assumption Really Mean That Labor Bears the Burden of a Capital Income Tax," Advances in Ecnomic Analysis \& Policy, 6:1 (August 2006).

Gruber, Jonathan, "The Incidence of Payroll Taxation: Evidence from Chile," Journal of Labor Economics, 15:3, Part 2 (1997), S72-S101.

Grubert, Harry, and John Mutti, "Do Taxes influence where US Multinational Corporations Invest?” National Tax Journal, 53:4 (December 2000), 825-849. 
Gwartney, James, and Robert Lawson, Economic Freedom of the World: 2005 Annual Report (Vancouver: The Fraser Institute 2005). Data retrieved from www.freetheworld.com.

Hall, Robert E., and Dale W. Jorgenson, "Tax Policy and Investment Behavior," The American Economic Review, 57:3 (June 1967), 391-414.

Hallerberg, Mark, and Scott J. Basinger, "Internationalization and Changes in Tax Policy in OECD Countries: The Importance of Domestic Veto Players." Comparative Political Studies, 31 (June 1998), 321-53.

Hallerberg, Mark, and Scott J. Basinger, "Globalization and Tax Reform: An Updated Case for the Importance of Veto Players," Poltische Vierteljahresschrift, 40:4 (1999), 618-27.

Hanson, Gordon H., and Robert C. Feenstra, "Foreign Investment, Outsourcing and Relative Wages", in Robert C. Feenstra, Gene M. Grossman, and Douglas A. Irwin (Eds.), Political Economy of Trade Policy: Essays in Honor of Jagdish Bhagwati, (Cambridge, MA: MIT Press, 1999), 89-127.

Harberger, Arnold C., "The Incidence of the Corporation Income Tax," Journal of Political Economy, 70:3 (June 1962), 215-240.

Harberger, Arnold C., "Corporation Tax Incidence: Reflections on What is Known, Unknown, and Unknowable," For conference "Is It Time For Fundamental Tax Reform: The Known, Unknown and Unknowable?" (April 2006).

Hassett, Kevin A., and G. Hubbard, "Tax Policy and Business Investment," in Alan J. Auerbach and M. Feldstein (Eds.), Handbook of Public Economics, Vol. 3 (2002), 1293-1343.

Hays, Jude C., "Globalization and Capital Taxation in Consensus and Majoritarian Democracies," World Politics, 56 (2003), 79-113.

Hines, James R., and Eric M. Rice, "Fiscal Paradise: Foreign Tax Havens and American Business," Quarterly Journal of Economics, 109:1 (February 1994), 149-182.

Jorgenson, Dale W., "Capital Theory and Investment Behavior," American Economic Review, 53:2 (1963), 247-59. 
Katz, Lawrence F., "Technological Change, Computerization and the Wage Structure," in Erik Brynjolfsson, Brian and Kahin (Eds.), Understanding the Digitial Economy: Data, Tools, and Research (Cambridge, MA: MIT Press, 2002), 217-243.

Kotlikoff, Laurence, and Laurence Summers, "Tax Incidence”, in Alan J. Auerbach and Martin S. Fedstein (Eds.), Handbook of Public Economics (Amsterdam: NorthHolland, 1987).

Leung, Danny, and Terence Yuen, "Do Exchange Rates Affect the Capital-Labor Ratio? Panel Evidence from Canadian Manufacturing Industries," Bank of Canada Working Paper (April 2005); available at: http://www.bankofcanada.ca/en/res/wp/2005/wp05-12.pdf.

Mutti, John, and Harry Grubert, "The Taxation of Capital Income in an Open Economy: The importance of Resident-Nonresident Tax Treatment," Journal of Public Economics, 27 (August 1985), 291-309.

Nunziata, Luca, "Institutions and Wage Determination: A Multi-Country Approach," working paper (2001); available at: http://ideas.repec.org/p/nuf/econwp/0129.html

Persson, Torsten, and Guido Tabellini, "Democracy and Development: Devil in the Details" (2005); available

at: http://www.aeaweb.org/annual_mtg_papers/2006/0106_1015_1402.pdf.

Poterba, James, "Retail Price reactions to Changes in State and Local Sales Taxes," National Tax Journal, 49:2 (1996), 165-176.

Rama, Martin, "A Labor Market Cross-Country Database" Washington, DC: World Bank, 1996).

Rama, Martin, "Globalization and the Labor Market", The World Bank Research Observer, 18:2 (2003), 159-186.

Randolph, William C., "International Burdens of the Corporate Income Tax," CBO Working Paper 2006-09 (August 2006).

Rodrik, Dani, "Democracies Pay Higher Wages," Quarterly Journal of Economics, 114:3 (1999), 707-738.

Solon, Gary, Robert Barsky, and Jonathan A. Parker, "Measuring the Cyclicality of Real Wages: How Important is Composition Bias," Quarterly Journal of Economics, 109:1 (1994), 1-25. 
United Nations Industrial Development Organization (UNIDO), Yearbook of Labor Statistics, various editions.

Figure 1: Corporate Tax and Wage Links, Panel Data, 1981-2005

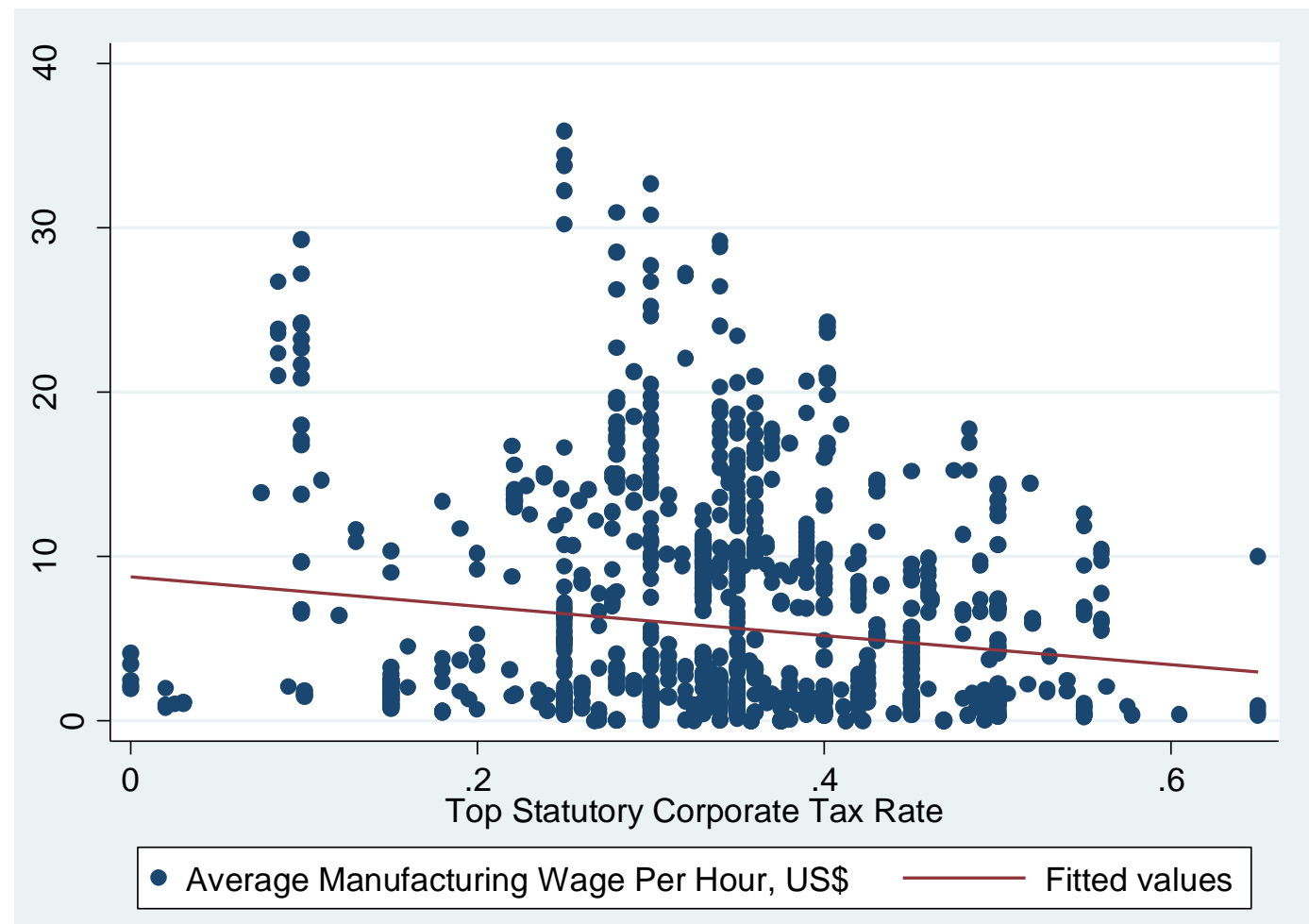


Table 1: Descriptive Statistics

\begin{tabular}{|l|l|l|}
\hline \multicolumn{1}{|c|}{ Variable } & Mean & Std. Dev \\
\hline $\begin{array}{l}\text { Average Wage Per } \\
\text { Hour, US \$ }\end{array}$ & 5.185 & 6.402 \\
\hline $\begin{array}{l}\text { Top Corporate Tax } \\
\text { Rate }\end{array}$ & .343 & .105 \\
\hline $\begin{array}{l}\text { Log (Capital- } \\
\text { Labor Ratio) }\end{array}$ & 9.979 & 1.176 \\
\hline $\begin{array}{l}\text { Effective Average } \\
\text { Tax Rate }\end{array}$ & .305 & .093 \\
\hline $\begin{array}{l}\text { Effective Marginal } \\
\text { tax Rate }\end{array}$ & .265 & .117 \\
\hline $\begin{array}{l}\text { Average Personal } \\
\text { Income Tax Rate }\end{array}$ & .263 & .097 \\
\hline $\begin{array}{l}\text { Capital Mobility } \\
\text { Price Level) }\end{array}$ & 4.264 & .607 \\
\hline $\begin{array}{l}\text { Value Added Per } \\
\text { Worker }\end{array}$ & 19776.44 & 14570.41 \\
\hline $\begin{array}{l}\text { Log (GDP per } \\
\text { capita) }\end{array}$ & 3.091 & .624 \\
\hline Log (Trade/GDP) & 4.108 & .609 \\
\hline Log (Schooling) & 3.845 & .607 \\
\hline ILO Conventions & & \\
\hline Log (Consumer & & \\
\hline
\end{tabular}


Table 2: Regressions Without Spatial Effects

\begin{tabular}{|c|c|c|c|c|c|}
\hline & $\begin{array}{l}(1) \\
\mathrm{FE}\end{array}$ & $\begin{array}{l}(2) \\
\mathrm{FE}\end{array}$ & $\begin{array}{l}(3) \\
\text { FE }\end{array}$ & $\begin{array}{l}(4) \\
\text { GMM }\end{array}$ & $\begin{array}{l}\text { (5) } \\
\text { OLS }\end{array}$ \\
\hline Log(Top Corp. Tax) & $\begin{array}{c}-.697 \\
(.281)^{* *}\end{array}$ & & & $\begin{array}{l}-0.259 \\
(.108)^{* *}\end{array}$ & $\begin{array}{l}-.978 \\
(.330)^{* * * *}\end{array}$ \\
\hline \multicolumn{2}{|l|}{ Log(Eff. Avg. Tax) } & $\begin{array}{l}-.632 \\
(.302)^{* *}\end{array}$ & & & \\
\hline \multicolumn{2}{|l|}{ Log(Eff. Marg. Tax) } & & $\begin{array}{l}-.385 \\
(.206) *\end{array}$ & & \\
\hline Log(Value Added) & $\begin{array}{l}0.431 \\
(.256)^{*}\end{array}$ & $\begin{array}{l}.365 \\
(.268)\end{array}$ & $\begin{array}{l}.401 \\
(.266)\end{array}$ & $\begin{array}{l}.050 \\
(.010) * * *\end{array}$ & $\begin{array}{l}.427 \\
(.254)^{*}\end{array}$ \\
\hline Log(Consumer Price $)$ & $\begin{array}{l}.539 \\
(.247) * *\end{array}$ & $\begin{array}{l}.624 \\
(.271)^{* *}\end{array}$ & $\begin{array}{l}.611 \\
(.275) * *\end{array}$ & $\begin{array}{l}.538 \\
(.040) * * *\end{array}$ & $\begin{array}{l}.446 \\
(.267)^{*}\end{array}$ \\
\hline \multicolumn{2}{|l|}{$\log ($ Wage,$t-1)$} & & & $\begin{array}{l}.656 \\
(.020)^{* * *}\end{array}$ & \\
\hline Constant & $\begin{array}{l}-6.172 \\
(2.366)^{* * *}\end{array}$ & $\begin{array}{l}-5.888 \\
(2.483)^{* *}\end{array}$ & $\begin{array}{l}-5.921 \\
(2.523)^{* *}\end{array}$ & $\begin{array}{l}-2.756 \\
(.193)^{* * *}\end{array}$ & $\begin{array}{l}-6.008 \\
(2.456)^{* *}\end{array}$ \\
\hline Period Dummies & Yes & Yes & Yes & Yes & Yes \\
\hline \multirow{2}{*}{\multicolumn{2}{|c|}{$\begin{array}{lr}\text { Region Dummies } & \text { No } \\
\text { Period x Region Dummies No }\end{array}$}} & No & No & No & Yes \\
\hline & & No & No & No & Yes \\
\hline Observations & 223 & 204 & 200 & 929 & 223 \\
\hline \multicolumn{6}{|c|}{$\begin{array}{l}\text { Standard Errors in parentheses } \\
* * * \text { significant at } 1 \% ; * * \text { significant at } 5 \% ; * \text { significant at } 10 \%\end{array}$} \\
\hline \multicolumn{6}{|c|}{$\begin{array}{l}\text { 2. In specifications (1)-(3) and (5), the dependent variable is the } 5 \text { year average of the wage rate over } \\
\text { sub-periods: 1981-1985, 1986-1990, 1991-1995, 1996-2000, 2001-2005. The independent } \\
\text { variables are the beginning of period values of these variables (except for the consumer price } \\
\text { variable which is also the five year average). In specification (4), we use annual data on wages. }\end{array}$} \\
\hline
\end{tabular}


Table 3: Regressions With Spatial Variables

\begin{tabular}{|c|c|c|c|c|}
\hline & (1) & (2) & (3) & (4) \\
\hline Weight: & Income & Income & Distance & Income \\
\hline Nbr. Group: & Region & Income & Income & Income \\
\hline Log(Top Corp. Tax) & $\begin{array}{l}-.727 \\
(.299) * *\end{array}$ & $\begin{array}{l}-.536 \\
(.299) *\end{array}$ & $\begin{array}{l}-.601 \\
(.308) *\end{array}$ & \\
\hline Log(Value Added) & $\begin{array}{l}.532 \\
(.254) * *\end{array}$ & $\begin{array}{l}.154 \\
(.290)\end{array}$ & $\begin{array}{l}.179 \\
(.294)\end{array}$ & $\begin{array}{l}.442 \\
(.285)\end{array}$ \\
\hline Log(Consumer Price) & $\begin{array}{l}.466 \\
(.251)^{*}\end{array}$ & $\begin{array}{l}.706 \\
(.246)^{* * * *}\end{array}$ & $\begin{array}{l}.617 \\
(.244)^{* *}\end{array}$ & $\begin{array}{l}.548 \\
(.271)^{* *}\end{array}$ \\
\hline Weighted Nbr. Tax & $\begin{array}{l}-.149 \\
(.238)\end{array}$ & $\begin{array}{l}1.195 \\
(.451)^{* * * *}\end{array}$ & $\begin{array}{l}.628 \\
(.324)^{*}\end{array}$ & $\begin{array}{l}-.028 \\
(.415)\end{array}$ \\
\hline Constant & $\begin{array}{l}-6.956 \\
(2.365)^{* * *}\end{array}$ & $\begin{array}{l}-3.367 \\
(2.675) \\
\end{array}$ & $\begin{array}{l}-3.786 \\
(2.706) \\
\end{array}$ & $\begin{array}{l}-6.335 \\
(2.588)^{* *} \\
\end{array}$ \\
\hline Observations & 223 & 223 & & \\
\hline \multicolumn{5}{|c|}{$\begin{array}{l}\text { Standard errors in parentheses } \\
* * * \text { significant at } 1 \% ; * * \text { significant at } 5 \% ; * \text { significant at } 10 \%\end{array}$} \\
\hline \multicolumn{5}{|c|}{$\begin{array}{l}\text { 1.All specifications include country fixed effects and period dummies. } \\
\text { 2.The dependent variable is the } 5 \text { year average of the wage rate over sub-periods: } 1981-1985,1986- \\
\text { 1990, 1991-1995, 1996-2000,2001-2005. } \\
\text { 3. The tax rate for the spatial variable corresponds to the tax rate used in the specification. In (1),(2) } \\
\text { and (3), the spatial neighbor tax rate is the top corporate rate. In (4), the effective average tax rate. }\end{array}$} \\
\hline
\end{tabular}


$\underline{\text { Table 4: Testing Robustness }}$

\begin{tabular}{|c|c|c|c|c|}
\hline & (1) & (2) & (3) & (4) \\
\hline Log(Top Corp. Tax) & $\begin{array}{l}-.527 \\
(.299) *\end{array}$ & $\begin{array}{l}-.528 \\
(.306)^{*}\end{array}$ & & \\
\hline Log (Eff. Avg. Tax) & & & $\begin{array}{l}-.572 \\
(.326)^{*}\end{array}$ & \\
\hline Log (Eff. Marg. Tax) & & & & $\begin{array}{l}-.399 \\
(.217)^{*}\end{array}$ \\
\hline Inc. Wt.Nbr. Tax & $\begin{array}{l}1.365 \\
(.492)^{* * *}\end{array}$ & $\begin{array}{l}1.277 \\
(.507) * *\end{array}$ & $\begin{array}{l}1.052 \\
(.626)^{*}\end{array}$ & $\begin{array}{l}1.264 \\
(.491)^{* *}\end{array}$ \\
\hline Log(Value Added $)$ & $\begin{array}{l}.102 \\
(.297)\end{array}$ & $\begin{array}{l}.144 \\
(.300)\end{array}$ & $\begin{array}{l}.239 \\
(.311)\end{array}$ & $\begin{array}{l}.258 \\
(.305)\end{array}$ \\
\hline $\log ($ Consumer Price $)$ & $\begin{array}{l}.870 \\
(.312)^{* * *}\end{array}$ & $\begin{array}{l}.868 \\
(.322)^{* *}\end{array}$ & $\begin{array}{l}.711 \\
(.348) * *\end{array}$ & $\begin{array}{l}.751 \\
(.346)^{* *}\end{array}$ \\
\hline Log $($ Trade/GDP $)$ & $\begin{array}{l}.242 \\
.282)\end{array}$ & $\begin{array}{l}.251 \\
.292)\end{array}$ & $\begin{array}{l}-.186 \\
(.345)\end{array}$ & $\begin{array}{l}-.138 \\
(.343)\end{array}$ \\
\hline Cap. Mobility & & $\begin{array}{l}-.025 \\
(.031)\end{array}$ & $\begin{array}{l}-.043 \\
(.033)\end{array}$ & $\begin{array}{l}-.033 \\
(.033)\end{array}$ \\
\hline Log(ILO Conventions) & & & $\begin{array}{l}.253 \\
.648)\end{array}$ & $\begin{array}{l}.396 \\
(.637)\end{array}$ \\
\hline Constant & $\begin{array}{l}-4.367 \\
(2.919)\end{array}$ & $\begin{array}{l}-4.586 \\
(2.980)\end{array}$ & $\begin{array}{l}-4.059 \\
(3.459)\end{array}$ & $\begin{array}{l}-4.767 \\
(3.443)\end{array}$ \\
\hline Observations & 223 & 216 & 182 & 181 \\
\hline
\end{tabular}

Standard errors in parentheses

***significant at $1 \%$; **significant at $5 \%$;*significant at $10 \%$

1.All specifications include country fixed effects and period dummies.

2.The dependent variable is the 5 year average of the wage rate over sub-periods: 1981-1985, 1986-1990, 1991-1995, 1996-2000,2001-2005.

3. The tax rate for the spatial variable corresponds to the tax rate used in the specification. In (1), (2) and (3), the spatial neighbor tax rate is the top corporate rate. In (4), the effective average tax rate. 
Table 5: Capital-Labor Ratios, Taxes and Wages

\begin{tabular}{|c|c|c|c|c|}
\hline & $\begin{array}{l}(1) \\
\text { K/L) }\end{array}$ & $\begin{array}{c}(2) \\
\log (K / L)\end{array}$ & $\begin{array}{c}(3) \\
\log (\mathrm{K} / \mathrm{L})\end{array}$ & $\begin{array}{l}(4) \\
\text { Log (Wage) }\end{array}$ \\
\hline Log(Top Corp.Tax) & $\begin{array}{l}.137 \\
(.058) * *\end{array}$ & & & \\
\hline Log(Eff. Avg. Tax) & & $\begin{array}{l}-.161 \\
(.073)^{* *}\end{array}$ & & \\
\hline Log(Eff. Marg. Tax) & & & $\begin{array}{l}-.093 \\
(.057)\end{array}$ & \\
\hline $\log (\mathrm{K} / \mathrm{L})$ & & & & $\begin{array}{l}.450 \\
(.176)^{* *}\end{array}$ \\
\hline Constant & $\begin{array}{l}9.876 \\
(.064)^{* * *}\end{array}$ & $\begin{array}{l}9.873 \\
(.090)^{* * *}\end{array}$ & $\begin{array}{l}9.949 \\
(.080)^{* * *}\end{array}$ & $\begin{array}{l}3.722 \\
(1.780)^{* * *}\end{array}$ \\
\hline Observations & 256 & 229 & 225 & 247 \\
\hline
\end{tabular}

Standard errors in parentheses

***significant at $1 \%$;**significant at $5 \% ; *$ significant at $10 \%$

1.The dependent variable is the 5 year average of the wage rate in (4) and the capital-labor ratio in (1), (2) and (3) over sub-periods: 1981-1985, 1986-1990, 1991-1995, 1996-2000,2001-2005. The independent variables are the beginning of period values of these variables. 


\section{Data Appendix}

\section{A.1 AEI International Tax Database}

The main sources of information for the data are: (1) The Price Waterhouse Coopers Corporate Taxes - Worldwide Summaries" and "Individual Taxes - Worldwide Summaries" (2) Coopers and Lybrand: "International Tax Summaries" (3) "Worldwide Corporate Tax Guide 2001" by Ernest \& Young (4) The International Bureau for Fiscal Documentation's Loose-leaf Service (5) Embassies and ministries of taxation in individual countries. Historical information was gathered from Georgetown Law Library and the Library of Congress. The most recent information was purchased from the PWC website:

(http://www.pwc.com/extweb/pwcpublications.nsf/docid/9B2B76032544964C8525717E 00606CBD) or printed out from the E\&Y website.

The Database consists of a number of spreadsheets containing information on a specific tax rate, the number of income tax brackets and the upper limit of each bracket (in local currency) and the tax rate in each bracket for about 128 countries. We chose countries based on data availability and to ensure a mix of developing and developed economies.

The database contains information on the following tax variables: (1) Personal Income Taxes (2) Deductions to Personal Income Taxes (3) Personal Dividend Taxes (4) Local Personal Taxes (5) Capital Gains Taxes (6) Corporate Taxes (manufacturing are reported separately) ${ }^{\mathrm{xxv}}$ (7) Local Corporate Taxes (8) Corporate Dividend Taxes (9) Corporate Capital Gains Taxes (10) Employer Payroll Taxes (11) Employee Payroll Taxes (12) VAT (13) Inheritance and Gift Taxes. It also provides information on the tax depreciation rules followed by countries. Depreciation rules are broadly based on the straight line method or the declining balance method or a combination of both. These rates vary across countries and were used in the calculation of the effective average and effective marginal corporate tax rates.

\section{Cross-country comparability issues}

The main differences across countries in corporate taxation arise due to various surcharges and additional contributions that are either (1) added to the base tax rates or (2) are imposed as a proportion of taxes payable. For instance, Barbados in 1991 added a 1.5 percent stabilization tax to all marginal tax rates. Brazil in 2005 imposed an additional 'social contribution' of 10 percent. The assumption we have made is that if the 
surcharge applies to all tax brackets, it is added to all the corresponding tax rates. In other cases, the surcharge is applied to all tax payable. In this case, all tax rates are multiplied by $(1+$ surcharge \%). For instance, Belgium in 2005 imposed a crisis tax of 3 percent, raising its total corporate tax rate to 33.99 percent from 33 percent. Canada in 1987 imposed a temporary $3 \%$ surtax on tax payable. All marginal tax rates were multiplied by 1.03. However, in some cases this is not possible since the surcharge applies only if the tax liability is above a certain level. In such cases, the marginal tax rate would vary for the high income and the low income groups depending upon the actual tax payments (net of deductions etc). If no further information is provided, in such cases the surtax is not included. For example, in Korea 1981-1990, there is a $10 \%$ defense tax on tax payable, which is increased to $20 \%$ for higher tax payers. The $20 \%$ surtax is not included in this database, while the $10 \%$ surtax is applied to all income levels.

Apart from the various surcharges and additional contributions imposed on the marginal tax rates, we have had to make certain assumptions while dealing with the data. Some of these are listed here. For more detailed notes, we would refer you to the AEI International Tax Database.

In Saudi Arabia, Saudi owned enterprises and the Saudi portion of joint enterprises are not subject to the corporate income tax. We have used the tax rate applicable to foreign firms.

In Thailand for certain years, the tax rate for companies listed on the stock exchange was lower than for those companies not listed on the exchange. We have used the rate for companies listed on the stock exchange. This is also true of Pakistan, where different rates apply to publicly listed companies compared to non-publicly listed companies. We have used the rate for the former.

In Canada, the national corporate tax rate is reduced by $10 \%$ to allow the provinces and territories room to impose corporate taxes. In general, whenever a country allows deductions of the local corporate tax from the national tax, these deductions are taken into account.

In Spain, there is a reduced rate for qualifying small businesses who earn up to a certain level of income (the actual number varies across years). This is not taken into account since it is not possible to distinguish between types of businesses or the number of years they are in operation.

\section{A.2 International Wage Data}

The statistics on wages are obtained from the ILO's Key Indicators of the Labor Market (KILM). The ILO reports average earnings per worker or, in some cases, average wage rates. Some of the series cover wage earners (i.e. manual or production workers) only, while others refer to salaried employees (i.e. non-manual workers), or all employees (i.e. wage earners and salaried employees). The series cover workers of both sexes, irrespective of age.

Earnings: The concept of earnings relates to remuneration in cash and in kind paid to employees, as a rule at regular intervals, for time worked or work done together with remuneration for time not worked, such as for annual vacation, other paid leave or holidays. In general, earnings exclude employers' contributions in respect of their 
employees paid to social security and pension schemes and also the benefits received by employees under these schemes. However, some countries report any such payments made. Earnings also exclude severance and termination pay.

Statistics of earnings should relate to employees' gross remuneration, i.e., the total before any deductions are made by the employer in respect of taxes, contributions of employees to social security and pension schemes, life insurance premiums, union dues and other obligations of employees.

Earnings include: direct wages and salaries, remuneration for time not worked (excluding severance and termination pay), bonuses and gratuities and housing and family allowances paid by the employer directly to this employee. (a) Direct wages and salaries for time worked, or work done, cover: (i) straight time pay of time-rated workers; (ii) incentive pay of time-rated workers; (iii) earnings of piece workers (excluding overtime premiums); (iv) premium pay for overtime, shift, night and holiday work; (v) commissions paid to sales and other personnel. Included are: premiums for seniority and special skills, geographical zone differentials, responsibility premiums, dirt, danger and discomfort allowances, payments under guaranteed wage systems, cost-of-living allowances and other regular allowances. (b) Remuneration for time not worked comprises direct payments to employees in respect of public holidays, annual vacations and other time off with pay granted by the employer. (c) Bonuses and gratuities cover seasonal and end-of-year bonuses, additional payments in respect of vacation period (supplementary to normal pay) and profit-sharing bonuses. (ii) Statistics of earnings should distinguish cash earnings from payments in kind. Wage rates: These include basic wages, cost-of-living allowances and other guaranteed and regularly paid allowances, but exclude overtime payments, bonuses and gratuities, family allowances and other social security payments made by employers. Ex gratia payments in kind, supplementary to normal wage rates, are also excluded.

Thus broadly country coverage differs due to the following reasons: (1) whether the reported statistic is wages or earnings (2) whether it covers employees, wage earners or salaried employees (3) whether it includes social security contributions by employer. When we studied the descriptions more closely, we found that certain countries like Chile, Turkey, Colombia, Ecuador, Kenya, Kyrgyzstan, Mexico, Malaysia, Panama and Ukraine included social security contributions by employers in the earnings data. Another difference arises because the industrial classification changed during this period. Since the beginning of the 1990s an increasing number of countries have made a switchover in their data reporting systems for industrial statistics from Revision 2 to Revision 3 of the International Standard Classification of All Economic Activities (ISIC).

Including dummies to allow for all these differences in coverage in a panel regression (without country fixed effects) yielded a highly significant negative sign on corporate tax rates, and no change in results for the other variables.

\footnotetext{
${ }^{\mathrm{i}}$ See Auerbach (2005) for a more recent analysis of who bears the burden of the corporate tax.

${ }^{\text {ii }}$ Corporate taxes have other distorting effects as well. They distort choices related to organizational form

of the business, lead to reliance on debt financing of firms and discourage dividend payouts (Hines, 2001)

iii “Corporate Income Tax Rates: International Comparisons”, November 2005, CBO
} 
${ }^{\text {iv }}$ Note that tax competition has been traditionally modeled as countries responding to other countries corporate tax rates by lowering their own, to attract investment. Our notion of tax competition refers to the flow of capital across countries in response to existing differences in tax levels. Such mobility is implicitly, rather than explicitly, modeled since we're studying wage determination in mostly open economies.

${ }^{v}$ This is not a balanced panel, since data on taxes is missing for several countries, both OECD and nonOECD.

${ }^{v i}$ Solon et al. (1994) suggest that aggregate wage statistics may be subject to severe composition bias. The aggregate wage statistic is a weighted average of earnings for different groups of workers, such as highwage or low-wage workers. Since hours of work of low-wage workers tend to be procyclical, this gives greater weight to low-skill workers in expansions, rather than recessions. Thus cyclically shifting weights may be a source of measurement error in aggregate wage data. We believe that our measure of wages is less subject to this criticism since we average the wage data for each country over five year periods, removing much of the cyclicality.

${ }^{v i i}$ Typically, real and nominal wage data are highly serially correlated (Nuniziata, 2001). However, since we use five year averages, this is less of a concern for us. In later specifications, we do use GLS estimation allowing for autocorrelation in the residuals, however the estimated autocorrelation coefficient is not significant and results do not change.

viii Access to the AEI International Tax Database can be provided by writing to the authors.

${ }^{\text {ix }}$ Our specification is also similar to Barro (2003) which uses beginning of period values of the explanatory variables to explain average growth rates over different periods of time. We have also tested our results using the average of the log wage rates as the dependent variable. Results were similar and in most cases the significance level went up as a result of using this specification. However, with no theory to guide us, we report results using the log of the average wage since the arithmetic mean (rather than the geometric mean) seemed a more intuitive specification to us.

${ }^{\mathrm{x}}$ Conceptually, the EATR can be expressed as follows,

$$
\zeta_{i}=\frac{\left(R_{i}^{*}-R_{i}\right)}{Y_{i}^{*}}
$$

where $R_{i}^{*}=Y_{i}^{*}-F_{i}$ is the pre-tax economic rent and $F_{i}$ equals the fixed cost. $R_{i}=\left(1-\tau_{i}\right) Y_{i}^{*}-\left(1-A_{i}\right) F_{i}$ is the post-tax economic rent calculated as the net present value of the income stream post-tax minus the net cost of the investment. $A_{i}$ is the net present value of tax allowances per unit of investment and $\tau_{i}$ is the statutory tax rate. In other words, the EATR summarizes the distribution of tax rates for an investment project over a range of profitability, with the EMTR representing the special case of a marginal investment.

${ }^{x i}$ To calculate EATR and EMTR, we assume an economic depreciation rate of $12.25 \%$, a real annual discount rate of $10 \%$ and an expected annual inflation rate of $3.5 \%$ for all countries and all years. These are the assumptions made by Devereux, Griffith and Klemm (2002). Author calculations are available upon request.

xii The coefficient on corporate taxes is negative and significant, even when we include both GDP and MVA in the analysis. Also, if we use only the countries with manufacturing value added data in the ILO sample, and use 3-year averages (to increase sample size), we are still able to reproduce our results.

${ }^{x i i i}$ http://homepage.newschool.edu/ foleyd/epwt/ . This data has been compiled by Adalmir Marquetti from the Penn World Table and other sources.

${ }^{\text {xiv }}$ This is not ideal since manufacturing is more capital intensive than other sectors, and therefore may be more responsive to capital costs than other sectors. However, we are unaware of a cross-country data source for manufacturing capital-labor ratios.

${ }^{\mathrm{xv}}$ For a list of countries with missing data, see Table 4D.

${ }^{x v i}$ The Gordon and Lee (2005) paper does not try to explain why the corporate tax has growth effects. It does not try to investigate the mechanism by which high taxation leads to perhaps lower investment, lower worker productivity and therefore lower economic growth.

xvii See Bloningen et al. (2005) and Franzese and Hays (2005) for an application of different spatial weighting matrices. 
xviii Immigration and trade flow linkages are likely to be better captured by using within region income weights rather than across regions, since geographic distance increases the costs of labor mobility and transportation of goods.

${ }^{x i x}$ Distances are calculated as the physical distance between two capital cities.

${ }^{x x}$ Gordon and Lee (2005) estimate the impact of corporate taxes on economic growth. They use neighbor tax rates as instruments for the domestic tax rate. We believe this is incorrect since both variables may have independent effects on growth and wages, and both therefore need to be included in the regression. Further, they do not consider different measures of the corporate tax rate, such as the effective average and marginal tax rates.

${ }^{\mathrm{xxi}} \mathrm{An}$ OLS regression of average wages on corporate taxes, schooling and (trade/GDP) (controlling for region effects and time dummies) alone yields significant and positive coefficients on schooling and (trade/GDP), while still yielding a negative and significant coefficient on corporate taxes. A regression of average wages on computerization or number of ILO conventions alone yields a positive and statistically significant impact of these variables.

xxii The classic studies of user costs and investment are Jorgenson (1963) and Hall and Jorgenson (1967), which develop a simplified user cost equation given by:

$c=\left(\frac{r-\pi+\delta}{1-u}\right)(1-u z)$ where $\mathrm{c}$ is the user cost, $\mathrm{r}$ is the nominal after corporate-tax discount rate that the firm must earn to attract investors, $\Pi$ is the rate of inflation, $\delta$ is the rate of economic depreciation, $u$ is the statutory corporate tax rate and $\mathrm{z}$ is the present value of depreciation deductions on a dollar of investment. . More recent studies include Auerbach (1983a, 1989), Auerbach and Hassett (1992, 2003).

xxiii While most studies of corporate taxation have focused on its impact on capital investment, it's likely that firms respond to high corporate taxation by adjusting labor. We do not explore this issue here, as it is sufficient for us to explore the elasticity w.r.t. K/L to test our results.

${ }^{x x i v}$ The 95 percent confidence interval for the corporate tax rate variable is $[-0.67,-0.10]$

${ }^{x x v}$ The corporate tax information is for corporations organized or created in the specific country or under the law of the country. A domestic corporation is a resident corporation even though it does no business or owns no property in the specific country. 